\title{
Protection of Public Interests in the Process of the Indonesian Proprietary
}

\author{
Etty Susilowati ${ }^{1}$, Paramita Prananingtyas ${ }^{1}$, M Fauzi $^{2}$ \\ ${ }^{1}$ Lecture at Faculty of Law, Universitas Diponegoro, Indonesia, \\ ${ }^{2}$ Lecture at Faculty of Law, Universitas Mulawarman, Indonesia
}

\begin{abstract}
Protection of public interests in the bankruptcy process is regulated in the Indonesian Bankruptcy Law. However, the implementation of this provision raises problems both in the concept design of the public interest itself and in its protection mechanisms. The bankruptcy law provides at least three concepts of public interest, each of which can be identified with the interests of the wider community as creditors, the interest in the stability of the financial services sector, and the interests of state finances. The three concepts of public interest are protected with exclusive and prerogative powers on the regulators and supervisors as the authority of each field. Such protection mechanisms have so far only blocked the path of creditors and debtors, and provided immunity to special debtors, as the majority of authorities do not want to file bankruptcy requests and prefer to exercise their public powers.
\end{abstract}

Keywords: Bankruptcy, public interest, legal protection.

\section{Introduction}

Bankruptcy institutions are needed as a special debt settlement mechanism. When debtors experience problems in completing their obligations to creditors, it can be generally assumed that the debtors are experiencing financial difficulties. This situation can encourage each creditor to try in various ways to get payment for assets that are assumed to be far below the value of all liabilities (common pool problem).If this situation is not properly facilitated, the resolution will result in problems leading to injustice, both for the debtor itself and the creditors. Some creditors may receive payment, even full payment while other creditors may get nothing. The position of debtors is getting more difficult because in addition to facing financial difficulties, debtors are also faced with claims from creditors who each want their receivables to be paid in full and prioritized over other creditors.

\section{Corresponding Author:}

Etty Susilowati

Lecture at Faculty of Law, Universitas Diponegoro, Indonesia

e-mail: ettysusilowati.undip@gmail.com
Bankrupt institutions cannot only be seen narrowly as a mechanism for settling debts and receivables between debtors and creditors. The complexity of transactions and the number of parties related to their interests, either directly or indirectly, also influence the dynamics and development of the bankruptcy institution ${ }^{1,2}$. The various interests involved in a debt settlement process demand that bankruptcy institutions be encouraged to take into account other interests affected by the bankruptcy process. Both creditors and debtors are not only bound by one legal relationship.As an economic being as well as a social being, both creditors and debtors certainly have rights and obligations to other parties or other roles in the social system of society. If the settlement of these debts and receivables is not carried out properly, it can be ascertained that both third parties and the wider community will more or less be affected. If one of the creditors does not get payment, it is possible that the creditor cannot pay the salaries of his employees or even has to close his business, so that it will impact on the family welfare of the employees ${ }^{3}$.Likewise, if it turns out that the debtor's business sector is urgently needed by the community, unstructured collections that unilaterally only pursue the settlement of accounts receivable can result in cessation of meeting the needs of the community, which was originally only supplied 
by the debtor's business ${ }^{4,5}$. It must be acknowledged that in certain situations the bankruptcy process and decision has an impact and influence on the interests of other parties and society in general, either directly or indirectly. The interests of other parties are directly harmed if the bankruptcy process results in the cessation of fulfilling the interests of that party, including if a bankruptcy decision is imposed on an entity/company whose products or services are used by the wider community. The bankruptcy process and decision can also harm the interests of other parties, indirectly, if the bankruptcy process affects and or hinders the fulfillment of the interests of the party, which, among other things, if the bankruptcy process causes anxiety and panic in the community.

This paper is based on nondoctrinal legal research that uses the standpoints of participants with inductive reasoning that empirically conceptualize law ${ }^{6,7}$. This research examines social realities in the form of the behavior of parties related to the protection mechanism of the public interest in bankruptcy and the relationship between these various symptoms as real legal manifestations $8,9,10$. The paradigm used is the postpositivism paradigm which ontologically sees that the reality of the public interest does exist but can never be fully understood (critical realism). Likewise, the public interest protection mechanism as outlined in legislation as a set of norms imposed on society, its enforcement will be greatly influenced by other factors (law as it is in society).

Public Interest in the Indonesian Bankruptcy Law: The settlement of accounts payable in the bankruptcy process is essentially taken over and controlled by the state through a panel of judges in the Commercial Court and curators. There are at least two possible purposes for the state's presence in the bankruptcy process. The first objective is to ensure that the settlement of accounts payable between debtors and creditors is carried out fairly. The next objective is to ensure that the settlement of debt and credit problems between creditors and debtors is not detrimental to wider interests. This is because the state in its position as administrator of the public interest also has an interest so that the settlement of rights and obligations between the debtor and its creditors does not interfere with the bigger interest. Thus, it is natural that the interests of the state in safeguarding the public interest are also considered in the process of settling these debts and receivables so that bankruptcy institutions not only protect the interests of debtors and creditors but also protect public interests ${ }^{11}$.

The Indonesian bankruptcy law regulates several bankruptcy mechanisms which are intended to protect interests outside the interests of debtors and creditors. Various interests outside the rights and obligations between creditors and debtors are protected in the bankruptcy process through public policy and authority and are given priority over individual interests, the authors assume, as the public interest ${ }^{12,13,14}$. This special mechanism gives authority to the Attorney General's Office, the Ministry of Finance and the Financial Services Authority (OJK) in submitting bankruptcy statements against certain debtors.Article 2 paragraph (2) of the Bankruptcy Law authorizes the prosecutor (public prosecutor) to file a bankruptcy application in the public interest when the requirements as referred to in Article 2 paragraph (1) have been met and no application for bankruptcy has been filed by another party. The concept of public interest in the explanation of these provisions is the interests of the nation and the State and or the interests of the wider community. This interest can arise when the debtor is not cooperative, embezzles assets or runs away. The public interest also arises when the debtor's debt is a fund that comes directly or indirectly from the wider community and/or SOES. The AGO has discretionary power in assessing the existence of other public interests. The public interest is essentially the main concept that underlies the birth of every statutory regulation. Likewise, the bankruptcy law carries the concept of public interest which is tried to be protected in the bankruptcy process. There are at least three concepts of public interest presented in the bankruptcy law. The public interest regarding the authority of the prosecutor's office in bankruptcy is the accumulation of the interests of many creditors. This is because the prosecutor's position is only as a substitute for creditors in filing a bankruptcy statement ${ }^{12,13,14}$.

Public Interest Protection Mechanism in the Bankruptcy Law: Based on the provisions in the Bankruptcy Law mentioned above, it can be concluded that there are 2 types of bankruptcy mechanisms, namely bankruptcy in general and bankruptcy with restrictions on the rights of debtors and creditors to apply for a bankruptcy statement. The differentiation of the bankruptcy mechanism is based on the type of interest being protected. A special mechanism in the form of limiting the rights of debtors and creditors to apply for a bankruptcy statement is provided to protect the public interest by taking into account the characteristics of the 
debtor who is filed for bankruptcy ${ }^{8,9,10}$. Based on their characteristics, debtors are grouped into three groups, namely debtors in general, debtors who are SOEs, and Debtors who are banks, insurance companies, reinsurance companies and pension funds, securities companies, stock exchanges, clearing and guarantee institutions, depository and settlement institutions.

This limitation is used as a counterweight considering the bankruptcy requirements based on the provisions of Article 2 paragraph (1) of the Bankruptcy Law are very simple and only require debt to two creditors, where the debt is due and can be collected, the debtor can be easily bankrupt through the trial process and brief evidence without the insolvency test. Such loose bankruptcy provisions are considered to be very dangerous to the interests of the wider community, especially if the debtors who are bankrupt are financial institutions and SOES. On the basis of these considerations, limiting Creditors' rights to file bankruptcy applications against specific debtors is considered a necessity to protect the larger public interest ${ }^{8,9,10}$. The concept of the Constitution states that such restrictions on rights can be established by law, on the condition that the limitation, although it looks as if it is imbalanced, but fulfills a rational balance. The fulfillment of the principle of balance in question is that the limitation is intended to protect the greater interest. In addition, for the party affected by the restriction, there are other alternative legal remedies that allow the party to fight for their rights.

Protection of public interest in bankruptcy has rational grounds and objectives. However, the concept and operationalization of the protection of public interests in bankruptcy still raises several fundamental issues, especially in relation to the concept of public interest which is the object of protection, whether the interest is an interest in bankruptcy or an interest outside bankruptcy, whether these interests are interests that already exist, do not exist, or only possible interests. This limitation of the concept of public interest is important because it becomes the basis of legitimacy for its protection efforts. Without clear evidence that there is a public interest there, there is no need for special protection measures that override the bankruptcy mechanism in general. Moreover, the Indonesian bankruptcy law has used an authoritative instrument in the form of restricting (revoking) the right to apply for a bankruptcy statement as a form of protection for the public interest.
The Indonesian bankruptcy law has used an authoritative instrument in the form of restrictions on who can file applications as a form of protection for the public interest. Limitation of this right can be interpreted as revocation of rights because in fact it has made the party that should have the right to apply for it not entitled to apply. Although the limited rights related to protection for the public interest are the rights of creditors in the field of formal law (procedural law) and on the other hand, the civil rights of creditors in the form of claims are legally recognized, guaranteed, and protected, however the construction of bankruptcy with this special mechanism is very different from the initial concept of bankruptcy as a debt settlement institution that gives creditor and debtor authority as parties who have rights and interests based on a civil law relationship ${ }^{15}$. The Minister of Finance and OJK as the authorities may have more adequate data and knowledge regarding the impact of bankruptcy status on financial institutions and SOEs so that they can take more appropriate policies and steps, but both basically have no interest and right to apply for a bankruptcy statement.

The number of requests for bankruptcy statements, submissions for judicial review to the Constitutional Court and the reluctance of the authorities given the authority to submit requests for bankruptcy statements are evidence that the protection system for public interest in bankruptcy with restrictions on the rights to file bankruptcy statements has not been a fair and effective solution. The resolution of the issue of protection of the public interest in bankruptcy cannot be done only by limiting the right to file a bankruptcy statement. If all issues of protecting the public interest in bankruptcy are carried out with restrictions on the right to apply for a bankruptcy statement, then it can be ascertained that the right to apply for a bankruptcy statement against all debtors will be with public institutions because aspects of the public interest will arise in all fields along with the increasing number and level of dependency society towards certain products and services.

\section{Conclusion}

The public and private dichotomy may have begun to fade as a result of the domination of the role of the state in all aspects of life. The role and interests of the state in bankruptcy to protect public interests cannot be avoided. However, the concept of public interest given by the bankruptcy law still raises several problems. Likewise, the exclusive and prerogative protection 
mechanism removes control over the use of this power by public institutions. Both resulted in unclear protection of interests in the private area and on the other hand created moral hazard from debtors who indirectly received immunity from bankruptcy. Along with the development of guarantee institutions for both public savings and policy guarantee institutions (which will soon follow), an evaluation of the authority of public institutions in filing a bankruptcy statement needs to be carried out to assess its urgency and minimize conflicts of interest between the interests of these public institutions as regulatory and supervisory authorities and interests. as the only party authorized to apply for a bankruptcy statement.

Conflict of Interest: There is no conflict of interest.

Source of Funding: This research was funded by the Diponegoro University Faculty of Law Research Grant Fund for the 2020 Fiscal Year.

Ethical Clearance: Ethical clearance from the institutional ethical committee obtained for the study.

\section{References}

1. Jackson TH. Bankruptcy, non-bankruptcy entitlements, and the creditors' bargain. The Yale Law Journal. 1982;91(5):857-907.

2. Jackson TH. Avoiding powers in bankruptcy. Stanford Law Review. 1984:725-87.

3. Baird DG. Loss distribution, forum shopping, and bankruptcy: a reply to Warren. The University of Chicago Law Review. 1987;54(3):815-34.

4. Jackson TH, Scott RE. On the nature of bankruptcy: An essay on bankruptcy sharing and the creditors' bargain. Virginia Law Review. 1989:155-204.
5. Jackson TH. The logic and limits of bankruptcy law. Washington, D.C: Beard Books; 2001.

6. Shidarta S. The Law of Reasoning and Legal Reasoning - Book 1: Philosophical Roots [Indonesian]. Yogyakarta: Genta Publishing.2013.

7. Irianto S., Shidarta S (Eds.). Legal Research Method: Constellation and Reflection [Indonesian]. Jakarta: Yayasan Pustaka Obor. 2013.

8. Barnet RE. Four Senses of the Public Law-Private Law Distinction. InForeword to the Symposium on the Limits of Public Law (Vol. 9).1986.

9. Pound R. Public Law and Private Law. Cornell LQ. 1938;24:469.

10. Wignjosoebroto S. Law: Concepts and Method [Indonesian]. Malang: Setara Press; 2013.

11. Suhelmi A. Western Political Thought [Indonesian]. Jakarta: Gramedia Pustaka Utama. 2001.

12. Veach JA. On Considering the Public Interest in Bankruptcy: Looking to the Railroads for Answers. Ind. LJ. 1996;72:1211.

13. Martin ND. Noneconomic Interests in Bankruptcy: Standing on the Outside Looking In. Ohio St. LJ. 1998;59:429.

14. Wardrop A. Theorising About Insolvency Law and the Public Interest in the Context of Insolvent Utilities: An Australian Perspective. Banking \& Finance Law Review. 2014;29(3):435.

15. SjahdeniSR. Jumlah Minimum Hutang dalam Undang-Undang Kepailitan. Suara Pembaharuan. 1998;26. 